Draft - Please do not quote - This version: 8 May 2004

\title{
War and the commons: assessing the changing politics of violence, access and entitlements in Sri Lanka
}

\author{
Benedikt Korf and Hartmut Fünfgeld
}

Ref. No. 353

Paper to be presented at the $10^{\text {th }}$ IASCP Conference, Oaxaca, Mexico, August 9-13, 2004

Sub-theme 2.3: Governance, Conflict and Institutional Reform

\begin{abstract}
This paper investigates the impacts of political violence on access to local commons and looks at local contests over resource entitlements under the condition of warfare and post-war transition in Sri Lanka. We map out two essential trajectories of refused and contested access to commons in the highly volatile institutional setting of war and post-war situations: On the one hand, the political geography of war and fighting creates "no-go zones". These often include local commons, such as jungle, lagoon and marine resources that become places of increased military contest. On the other hand, threats, intimidation and violence to admit or refuse access to resources for the 'ethnic other' is utilized as an essential instrument in the local contestations over ethnic identity, historical entitlements and discourses of spatial claims. In this volatile setup, social and political capital play crucial, though highly ambiguous roles for accessing the commons, and they are subject to continuous value change, depending on the political developments of the conflict. We illustrate this dynamism using two case studies of local common-pool and open-access resource systems in the war-affected east of Sri Lanka. In the first case study, we describe local contests over water distribution in a large-scale irrigation scheme located in a multi-ethnic area. In this case, farmers utilize their hydraulic positions within the irrigation set-up for both, gaining material advantages (diverting more water for irrigation) and using water as a means of power against the "ethnic other". Spatial access to water and land may be actively denied by physical violence or discouraged by intimidation. In doing so, civilians are embedded in a complex clientele network with local political and military power holders. The second case study highlights issues of changing access rights and resource use patterns in a large lagoon ecosystem. Since the lagoon was part of a militarily contested terrain during times of war, this produced severe access restrictions and security problems for local customary resource users. When overt violence came to a halt with the signing of a ceasefire and access was open again, a large number of customary and new users started exploiting lagoon resources, which led to increasing interand intra-community tension and resource overexploitation. Both case studies illustrate the volatile, polarised and hybrid nature of local institutions which produce a governance failure. These failed institutions undermine local peace building, because they feed back into existing political grievances.
\end{abstract}




\section{Introduction}

In many developing countries, common pool resources form the immediate basis of livelihood for the poor segments of the rural population. In times of civil warfare, it is the rural population who, due to economic constraints, lack of formally acquired skills that they could employ on the labour market, and the lack of large social networks, is unable to move out of the conflict area and hence continues to rely to a large extent on the remittances of natural resources, which often become the theatre of warfare, fighting and violence. The landless are particularly vulnerable to external shocks, since their revenues often rely at least partly on the benefits drawn from common property. In times of social unrest and political instability, common pool resources and their access regimes, too, undergo constant alterations. Thus, resource dependent families who are not able to take refuge outside the disputed area often face double hardship, since they on the one hand suffer from the effects of warfare through the loss of assets and the constant threat to life, while, on the other hand, they are no longer granted access to common property resources that determine their livelihoods. This dynamism reflects a set of political, social and economic 'war' phenomena that, as this paper will show, can be summarized as the political geographies of war multiple political developments at the macro-level leading to a transformation of the security situation and subsequent institutional changes at the micro-level. Our point here is to show how the political geographies of war affect access rights and entitlements to common property resources and thereby severely impinge on the livelihood opportunities of resource users.

Most research on the nexus of resources and violent conflict has focused on resource competition and environmental degradation as a source of social conflict and war (e.g. Baechler et al. 1996; Hauge and Ellingsen 1998, Homer-Dixon 1999). The common notion that resource scarcity would increase the likelihood of conflict has recently been contested by some peace researchers who argued that rather resource abundance created the opportunities and incentives for actors to start a rebellion in order to monopolise benefit streams from resources (Collier and Hoeffler 2002; De Soysa 2002; Elwert 1997; Keen 1997, 1998). This literature referred to economies of war and markets of violence where conflict entrepreneurs would loot available resources. These studies on warlordism have overshadowed more refined research on the exact mechanisms of local resource access in times of warfare or postwar transition processes. Among the few studies that have taken up the latter issue, Unruh $(1998,2001)$ investigated property rights in the post-war transition process of Mozambique. 
Also, Alston, Libecap and Mueller (1999) studied property rights under conditions of political violence in the Brazilian Amazon region - even though not a civil war as such. Suliman (1999), in a case study from central Sudan, exemplified how resource scarcity and diminishing access to natural resources was one of the major catalysts for social conflict and violence. In a conceptual paper in the same volume, Bush and Opp (1999) emphasize the interplay of resources and their attributed symbolic meanings in conflict-prone settings.

The lack of empirical evidence from the micro-level is understandable in the light of security concerns and unresolved ethical questions of undertaking social research in war-torn areas. However, there is an urgent need for micro-level studies, because civil and guerrilla warfare, which is rising significantly in scope and scale worldwide, mostly takes place in wider rural spaces, which are a strategic retreat for fighters. These areas often are at the same time significant open access or common pool resources on which a large part of population especially the poor - depends for their survival. This paper seeks to fill the apparent gap in the literature and investigates the local politics of access and entitlements in common property regimes in times of ongoing civil warfare and under post-war conditions, taking Sri Lanka as an example. An increased knowledge of socio-political processes in times of war and conflict transition may hold important implications for post-war reconstruction and reconciliation measures.

We will illustrate how the dynamics of the conflict situation in Sri Lanka have produced different types of local contests over resource entitlements, which epitomize the political economy of war and pinpoint to the institutional complexity of a multiethnic conflict at the micro-level. In doing so, we will follow two different trajectories of contested resource access and illustrate them with case studies from Sri Lanka's war-affected north-east. The case studies presented here point to two determinants of changing entitlements and access to resources in times of war and conflict. At the macro-level, the military and political actors issue security policies and subsequent access restrictions - formally by legal order, or informally by threat to assets and lives. On the micro-level, civilians themselves are a dynamic agent of institutional change. They make use of the void created by institutional failures and proactively seek to alter entitlements and resource access. Within civil society, horizontal intra-group linkages (based on social capital) and dissociation from the 'ethnic other' can lead to internally strengthened, but highly segregated ethnic or religious communities that may be prone to political instrumentalisation from radical groups within the community and to victimisation from external communities' powerholders. As we will 
illustrate, vertical political contacts and alliances (political capital) to a large extent determine a group's ability to instrumentalise ethnicity or religious affiliation.

\section{War and the disposition over resources: Entitlements, fields and capital}

In this paper, we are particularly concerned about the endowments and entitlements of people depending on common-pool or open-access resources. The environmental entitlements approach (Mearns 1995, Leach, Mearns and Scoones 1999) defines institutions as 'regularised patterns of behaviour between individuals and society' (Mearns 1995: 103) and considers these as central agents of mediation between the social and the environmental sphere. The approach is no doubt very instrumental in understanding the social factors that determine common property resources, since it focuses on dynamic institutions of intracommunity relations that are based on the heterogeneity of communities, their local history and power politics. However, since we are particularly concerned with the analysis of microlevel conflicts over common property in times of institutional failure (such as during war), we shift the focus to the politics of access (Ribot and Peluso 2003), because the concepts of entitlements of both Sen (1981) and Leach, Mearns and Scoones (1999) tend to remain in a rather legalistic framework. Especially Sen was more concerned with issues of moral philosophy than power analysis (Gore 1993). The entitlements approach can only partly explain the volatile social and political processes triggered by institutional failure in times of war. Ribot and Peluso (2003) have therefore argued that Sen's and others' rights-based theories do not take sufficient account of structural and relational mechanisms of gaining access to resources, i.e. they tend to neglect the politics of resource governance. The reference of environmental entitlements to having 'legitimate effective command' (Leach, Mearns and Scoones 1999: 233) over environmental goods and services is difficult to apply to civil wars, as the evidence on who legitimately commands over resources is often highly contested and blurred by politicisation and, in our case, 'ethnicisation'. In times of open conflict, established institutions tend to be highly volatile and subject to continuing changes. They often turn inoperative, and 'regularised patterns of behaviour' can be altered substantially within a short period of time. Likewise, environmental entitlements are subject to social and political upheaval.

In order to understand these distorted dynamics in the light of warfare, we resort to Bourdieu's resourceful social theory and his notions of 'field', 'capital', and 'strategy' (Bourdieu 1985, 1992, 2000). According to Bourdieu, people's social practices, that is 
choices and actions, are embedded in an objectively structured social space he calls 'fields' (Bourdieu 1985). Therefore, individuals belonging to a certain field - the Sri Lankan conflict can in that sense be called a sub-field of a larger political field identified by Bourdieu (2000) - are acting within the boundaries of certain rules they unconsciously adhere to. In our example, if people cannot escape the sub-field of conflict and war by taking refuge outside the conflict environment, they are under compulsion to stick to the rules that dominate the field - the institutional peculiarities of the conflict that dominate social life at the micro-level, within villages and households. Otherwise they run the risk of being excluded from the field ${ }^{1}$, which would mean imprisonment, abduction or, in the worst case, death. In order to sustain themselves and their families, most individuals would therefore automatically stick to the rules of social practice specific to their field. Within that, however, the social practice of individuals is determined by the disposition over resources, which in Bourdieu's terminology are called 'capital'(Bourdieu 1985, 1992). Here, the theoretical ties to Sen's entitlement approach (Sen 1981) become apparent.

In Bourdieu's concept, the notion of capital is deeply rooted in the structure of the field. In each field, a specific kind of capital - such as economic, social, political or symbolic capital is best suited to gain or maintain power (Bourdieu 1985). As our observations suggest, social and political capital are of prime significance in the sub-field of conflict. Social capital ${ }^{2}$ is defined by Bourdieu as resources that are linked to a durable network of 'more or less institutionalised relationships of mutual acquaintance or recognition' (Bourdieu 1985, cited in Portes 1998: 3). Social capital, therefore, looks at the social dispositions of an individual at the horizontal level, which is based on affiliation to a certain group. While Bourdieu did not expand on the definition of political capital, it is often perceived as links between an individual or a group to power structures (Baumann 2000: 20), particularly to the administrative, political and - in the context of violent conflict - military power holders. Political capital therefore can be understood as vertical links to political power, although the latter may be accessed through horizontal networks of patronage and clientelism. In Bourdieu's model, the distribution of capital between different actors may induce a change of the field's structural parameters. In other words, a field's structure directly reflects the distribution of capital among individual actors or institutions, i.e. the relations of power

\footnotetext{
${ }^{1}$ Here, the spatial reference of Bourdieu's fields is revealed. He often used the term 'space' as substitute for fields (e.g. in Bourdieu 1993).

${ }^{2}$ While it is not the purpose of this paper to analyse the various notions of social capital that have appeared within the social sciences over the past years, it is noteworthy to mention that Bourdieu was not only the one to come up with the concept, but, according to Portes (1998: 3) also provided 'the most theoretically refined' analysis of the term.
} 
(Bourdieu 1993). Therefore, fields in general are also battlefields of power, and power structures are constantly altered using different strategies. This agonistic perspective makes Bourdieu's model particularly applicable to the analysis of dynamic and convoluted conflicts.

\section{The political geographies of war in Sri Lanka's northeast: Local contests over CPRs}

To take account of the complexity of the so-called 'ethnic' conflict in Sri Lanka's northeast, it is more appropriate to talk about a 'conflict cocktail' rather than suggesting a one-dimensional, clear-cut political divide at the core of the violent clashes. Social and political cleavages occur at various levels, and many contestations over territories and resources go well beyond simple dichotomies of the type 'Sinhalese-Tamil'. Since the signing of a ceasefire agreement in 2002 the conflict evolved into a multitude of directions with dramatic political changes, particularly in the eastern part of the island. Here, the TamilMuslim divide has been further aggravated, with the Muslim leaders politicising their aspirations while the LTTE remained hesitant in granting the Muslims a political voice in their proposal for an 'Interim Self-Governing Authority' laid out in autumn 2003. In spring 2004, internal lines of dissent became apparent in the LTTE, when the organisation's military commander in the Eastern Province, Vinayagamoorthi Muralitharan (with nom-de-guerre Karuna) openly demonstrated his illoyality to the mostly Jaffna-based LTTE leadership. Despite the rapid defeat of the Karuna-movement, the uprising has been a further sign of the increasing political complexity of the war, as it has added an intraethnic component to the conflict. The increasing convolution of the conflict is also experienced at the micro-level.

The two-decade long conflict has greatly affected social integrity at the micro-level. We will follow two trajectories, exemplified by two case studies, which underline how the volatile political geographies of war can change the intra- and intercommunal institutional dynamics with regard to common property resources. First, local level conflicts over 'ethnicised' entitlements are portrayed as one outcome of the downward projection of the Sri Lankan conflict. Second, we highlight how local contests over resources have in several cases been aggravated by livelihood destruction, which was triggered by uncontrolled and unsustainable use of the commons. Both cases show that local institutions are a vital part of the convoluted conflict setting and as such are incapable of addressing the regulative needs of common property use. 
The case studies presented in this paper reflect the empirical evidence gathered by the authors in two different time slots. Research for the first case study (Allai Extension Scheme) was carried out in two phases. The first research phase took place from July to October 2001, and the second phase after the signing of the ceasefire agreement, in summer 2002. The second case (Mavilangathurai fishing village) illustrates the local level situation after almost two years of ceasefire. Empirical research was carried out from November 2003 to February 2004. This means that while we were able to study institutions of resource governance in the period briefly before the ceasefire agreement and immediately after, data about more distant periods of the civil war needed to rely on retrospective information, which is often distorted by present experiences of the informants. It is also important to bear in mind that the ground level situation may change rapidly and dramatically, depending on the political developments at the macro-level (i.e. peace negotiations between the LTTE and the government, but also internal friction within both parties; see above) and that this will have significant repercussions for the corresponding institutional arrangements.

Empirical research for both case studies was undertaken by the authors in close cooperation with Sri Lankan researchers and assistants. The research teams to a large extent focussed on qualitative data collection methods, such as key informant interviews with government officials, NGO staff, village elders, politicians, focus group discussion with farmers (Allai case) or fishermen (Mavilangathurai case), women and youth in the communities. Several data collection techniques of the rapid rural appraisal (RRA) toolbox were employed (e.g. social resource maps, mobility maps, Venn diagrams, environmental histories). In the Mavilangathurai case study, a quantitative household survey was administered that covered a range of issues of livelihood security.

\subsection{Case 1: Allai Extension Scheme: Local contests over 'ethnicised' entitlements}

In the war-affected northeast of Sri Lanka, competing claims and disputes over land exist between the Tamils and the Sinhalese, the Tamils and the Muslims, as well as the Sinhalese and the Muslims (Korf 2003d). These rival claims to land are rooted in the memory and perceptions in the context of the politics of ethnicity and colonization in Sri Lanka. Many Tamils have perceived the expansion of Sinhalese settlements in the Northeast as an act of political and geographic 'colonization of traditional Tamil areas'. The Sinhalese saw it as an expansion into areas that they had abandoned in ancient times. Influential bodies and actors in the two major conflicting parties - the Tamil versus the Sinhalese political constituencies - 
have developed ideological underpinnings for the respective claims for land and space in the Northeast, based on constructing the past and delineating historical claims for land. Scholars from both sides have attempted to justify the politics with numbers and maps. While Tamil scholars have enumerated the 'change in population ratios' in the East that eroded the Tamil majority position, in particular in Trincomalee and Amparai districts (Balasundarampillai 2002; Manogaran 1987; Tambiah 1986), nationalist Sinhalese scholars have often argued that the colonization schemes largely touched unoccupied land, and thus did not expel Tamils from any land (e.g. Peiris 1991, 1994; Hennayake 1985). In these discourses, the Muslims as a significant minority in the east of Sri Lanka are mostly left out. ${ }^{3}$

Allai Extension is such a large-scale irrigation and settlement scheme established in the 1950s that provided land to Sinhalese settlers from outside the district as well as to Tamil and Muslim peasants from the vicinity and was, as such, part of the wider peasant colonization ideology of the state. The politics of colonization overshadow access and entitlement conflicts over sharing of water in the irrigation scheme, because opportunistic behaviour of farmers who withdraw more water than they were allocated is too easily reshaped in terms of inter-ethnic struggles and grievances. As it stands, the hydraulic layout and allocation of land plots in the scheme has favoured Sinhalese farmers that received the land in the upstream area of the scheme. Water disputes between upstream and downstream farmers that may be a common phenomenon in many irrigation schemes, have often received an 'ethnicised' stance in the perceptions of the local farmers. This perceived ethnicisation of entitlements has grown in intensity with the outbreak of the civil war, because the state was weakened in its capacity to enforce the rules. In addition, the state was often perceived as being biased and, though possibly able, in fact not willing to enforce the rule of law if it disfavoured its own clientele, the Sinhalese settlers.

The strategic importance of the Sinhalese settlers increased with the escalation of the violent conflict, because these were the frontier men of the Sinhalese claims to the northeast (Thangarajah 2003). The state as one of the two combatant parties had an interest in keeping the Sinhalese settlers occupying their land, even though they lived under constant threat of being attacked from the LTTE. The state had, on the other hand, also an interest in pretending a "normal" state of affairs as much as possible, because this was crucial in order to place the LTTE in the terrorist trap, while the Sri Lankan state could claim to be the representative of

\footnotetext{
${ }^{3}$ In the Sri Lankan context, Muslims, though a religious group, perceive themselves as a distinct own communal group, besides Tamils and Sinhalese. In Sri Lanka's east, most Muslims will speak Tamil as a language, but they will still feel as a different group and do not perceive the LTTE as "their boys" as many Tamils do.
} 
all citizens, i.e. also the Tamils, who needed to be protected against the 'terrorists'. In fact, Allai Extension Scheme continued to function almost throughout the years of civil warfare. However, the scheme was divided into one part, inhabited by Sinhalese settlers and highly protected by army and police against the 'terrorist' threat, and those areas where Tamils and Muslims lived. Here, the army also exercised a firm control, however, in a different role. While army and police sought to bring security to their Sinhalese settlers, these 'security forces' were perceived by Tamils rather as an occupying force and Tamil citizens lived under constant fear of being arrested under suspicion of collaboration with the LTTE.

On the other side of the coin, the LTTE had established an informal reign of power, extracting taxes from the local population and exercising their own rules and laws. This situation brought especially Tamil peasants in a delicate situation: on the one hand, they needed to cooperate with the LTTE at least up to a certain extent, while on the other hand making sure that the security forces would not arrest them as LTTE collaborators. For Sinhalese peasants, the frontline was of course more clear-cut, with the LTTE as the enemy and the 'security forces' as their protectors. Nevertheless, also Sinhalese farmers were forced to pay taxes to the LTTE, because the army was not able to provide proper protection of its 'own' peasants during night time. The Muslims, on the other hand, did not have either side to resort to with full confidence. While the LTTE extracted taxes from Muslims, especially from traders and farmers, the army could provide some protection, but would not be perceived in such intimate terms as it was by the Sinhalese peasants.

The state machinery in Sri Lanka's northeast was similarly vexed. Many top-level administrators were upper caste Tamils, which had sympathy with the LTTE's demand for an independent homeland. In their professional capacities they were, however, aligned with the Sri Lankan state, which fought against the LTTE. Due to the strong informal influence of the LTTE, these administrators were forced to satisfy either side and preferred not to expose themselves in any conflict-sensitive matter. As a matter of fact, any government officer would be carefully scrutinized according to ethnic affiliation. Here, too, the Tamils were in a particularly delicate situation because they had to serve two masters at a time. These convolutions in the day-to-day government work significantly reduced its capacity to move forward and take action in case of entitlement and access conflicts. The preferred strategy was often to bury the head in the sand whenever a case ran the risk of causing trouble with any of the two masters.

This specific setup of structures and rules is mirrored in the micro-politics of water distribution in the Allai Extension Scheme. The geographical location of certain paddy fields 
has created a differentiated system of entitlements to water: hydraulically, the Sinhalese upstream farmers have the strongest position, since they can easily block the water supply to downstream farmers. They often divert more water than is allocated to them in order to cultivate encroached paddy fields. This, in turn, leads to water shortage on fields located more downstream in the system that largely belong to Tamils and Muslims. Such opportunistic behaviour can be found in many irrigation schemes, and detailed studies have been undertaken as to how such opportunism could be overcome with involving local farmer organizations in the management of such schemes (see, for example, Uphoff 1996).

In our case, however, we find a different story. In times of ethnic struggle, opportunistic behaviour against the "ethnic other" seems to be justified in normative terms, much more than what would be acceptable within the 'ethnic self'. In fact, the Sinhalese peasants who divert more water than officially allocated to them take different strategies to prevent the technical support staff of the irrigation scheme, largely Tamils, from rectifying the situation and ensuring the adequate flow of water to the downstream fields. For example, Sinhalese farmers would report to the police and army posts when the Tamil engineer effectively interfered with their practices. Since the technical irrigation office is located in the vicinity of the local police post, it is easy for police officers to informally exercise sufficient pressure on the Tamil government officers not to take action. Commonly, since the Tamil officer anticipates this reaction, he will not take any action in the first place anyway. Such power plays - which illustrate the use of and the reliance on strong political capital (support by police and army) - ensure that entitlements to water are extended for Sinhalese at the cost of water entitlements of Tamil and Muslim farmers downstream. Most affected in this scheme seem the Muslim farmers, since they are situated at the tail end, which hardly receives any water at all.

Further downstream, the story becomes even more fragmented. Here, Tamil and Muslim fields, often traditionally owned plot of lands, are situated close to each other and intertwined. Thus, Muslim farmers, living in the nearby town, need to walk through Tamil villages and/or cross Tamil fields in order to carry out cultivation. Initially, this did not pose any problem, because Tamil and Muslim livelihoods were closely intertwined in trade, marketing and cultivation. In the 1990s, however, the communal relationships between Tamils and Muslims deteriorated and have not yet fully recovered. Therefore, a general level of suspicion between the two ethnic groups continues to exist in the area. These developments had serious implications for the entitlements, especially of the Muslim peasants: In times of ethnic troubles or security incidences, Muslim farmers would be afraid 
of going to their fields, because they could be attacked by rebels who have a strong influence in the area and control large parts of it during the night. If such incidences happen during crucial times of the cultivation season (e.g. harvest), Muslim farmers may lose their whole harvest and investment. Some Muslim land owners have thus leased out their land to Tamil farmers, often to unfavourable conditions. Some Tamil farmers also refuse to pay their land lease and threaten to inform LTTE if the Muslim land owner got the police involved in order to retrieve his money. In addition, some Muslim paddy lands are situated in uncleared area (i.e. controlled by the LTTE), and the rebels do not allow Muslims to enter those areas to cultivate their land. Thus, in this case, Muslim farmers face a serious entitlement failure. ${ }^{4}$

In the aftermath of the ceasefire agreement in 2002, this area has become one of the troubled spots, where repeated Tamil-Muslim clashes and violent fighting erupted between gangs from both sides. Here again, access to water and to fields became part of the struggle: For example, in Tamil-Muslim clashes in early summer 2002, less than half a year after the ceasefire agreement was signed, Tamil farmers blocked the water to fields located further downstream which belonged to Muslims living in the nearby town. This indicates that entitlements to water became part of the power struggle and thus highly intertwined with the ethnic conflict.

\subsection{Case 2: Mavilangathurai fishing village: Failing institutions in times of conflict transition}

Mavilangathurai is a Hindu fishing village with 230 households situated in the government controlled ('cleared') area, on the shores of Batticaloa lagoon. The lagoon is the largest of its kind on Sri Lanka's east coast, extending about $56 \mathrm{~km}$ from north to south. It provides the basis for a diverse range of resource-based and mostly small-scale income earning activities. Primary forms of resource use, such as various modes of fishing and - recently introduced aquaculture, serve secondary small-scale industries, e.g. fish trading and lime making. Virtually all households in Mavilangathurai are dependent on the lagoon for their income, which they customarily derive from small-scale fishing using simple fishing methods (e.g.

\footnotetext{
It is important to note that Muslims are not all losers in the war. In much of Muttur areas, where Allai Extension Scheme is situated, it is Muslim traders that dominate commerce because Tamil traders face trouble with the army when passing checkpoints. Thus, Muslims, who are not suspected to collaborate with the LTTE, can easily form informal alliances with army officers, bribe them and carry out their trade business. However, they also have to pay taxes to the rebels. Most of the Tamil paddy cultivators thus depend on the services of Muslim traders. Suffice to say that this, again, has created grievances among Tamil farmers, claiming that Muslim traders would abuse their low bargaining power and buy their produce at low prices (Korf 2003, 2004).
} 
cast nets, gill nets, lines, and fish traps). The village is neighboured by a Muslim and a Christian Tamil settlement.

In Mavilangathurai, local institutional and political parameters that determine resource access and the modes of resource use underwent drastic alterations in the course of the conflict. These developments can be summarised into three phases, which will be addressed in detail in the following case study. They largely correspond to the political and military evolution of the conflict in Sri Lanka's northeast:

1) Relative institutional stability - conflict aggravation (up to 1990);

2) Institutional breakdown - open violent conflict (1990-2002);

3) Institutional 'derangement' - ceasefire and conflict transition (since 2002).

In Mavilangathurai, access to the lagoon resources (i.e. fish, crabs, prawns, shells) used to be officially governed by the national fisheries department, which has branch offices on the district level and mainly works through fisheries inspectors and village-level Fisheries Cooperative Societies (FCS). The FCSs are registered societies under the Co-operative Society Law of 1972. Their main purposes are to provide various types of loans from internal and external funds, to provide savings facilities for fishermen, and the conservation and management of fisheries resources (DSRoSL 2001). However, the performance of the FCSs, which were introduced from 'top-down' by the fisheries department in a step towards community-based resource management, vary greatly, both in space (e.g. between villages) and in time. They range from well organised societies that are able to offer a variety of services to its members, to those merely existing in the records of the fisheries department, with no real mandate or function. According to the fishermen in Mavilangathurai, their society, established in 1982, initially functioned well and was able to assist them with their professional needs. At the time, virtually all fishermen were registered members of the society and contributed an initial lump-sum subscription fee, plus a monthly membership fee. The government provided fishing canoes and gear to the society, which could be used and, under certain conditions, bought on a leasing scheme by the fishermen. However, the FCS remained an externally imposed institution with little momentum for self-reliance and internally stimulated growth, and many issues concerning fishing would have been discussed, assessed and settled informally, outside the institutional frame of the FCS. Nevertheless, the organisation's monopoly in providing professional services to the fishermen and its direct link to the state administration created a considerable level of authority, which had wideranging effects on resource access and use in Mavilangathurai. The FCS, at the time, served 
as formal institutional arena for information exchange and decision-making. In reference to Bourdieu's theory, the FCS was a means of pooling the 'professional' social capital that was built up over generations of fishermen in Mavilangathurai in order to derive benefit streams from state services. Therefore, social capital, institutionalised through the FCS, was an important channel for drawing economic profit from the resource without jeopardising one's economic opportunities in the village. This explains why nearly all fishermen were members of the FCS.

In order to understand the institutional dynamics of the FCS, we need to examine its role as a highly political organization with a direct link to the government. Maintaining the integrity of the FCS was crucial to the whole fishing community, since government funding greatly depended on the functioning of the society. Thus, the fishermen's political capital, broadly understood as vertical linkages to power structures, was vested to a great extent in the FCS. The society acted as important lobbyist for the needs of the fishermen as an economically and socially marginalised group. However, it is important to stress that internal conflict did occur, and the FCS seems to have been characterised by a vivid internal power play, where powerful actors derived considerable profit while others lost out. Individual power linkages had to be established and constantly renewed within the hierarchically structured FCS. While it is difficult to assess the details of the power dynamics in retrospective, i.e. who gained and who lost out on the state support provided, it is important to note that the FCS was the single most important link to legally access government services for the fishermen. Towards the outside world, the FCS thus served as an avenue for the fishermen's pooled social capital, which was transformed by certain powerful players (usually the wealthier fishermen who were literate) into political capital, using existing institutional channels provided by the state. This notion of the FCS as a highly contested and political institutional space is crucial in the understanding of the micro-level manifestations of the ethnic conflict.

The FCS in Mavilangathurai ceded to operate in 1990, after major ethnic riots had turned into a violent war in Batticaloa district. The front line between areas under control of the Special Task Force (STF), i.e. the Sri Lankan army, and those controlled by the LTTE ran along the longitudinal axis of the lagoon. Mavilangathurai found itself right in the eye of the continually evolving conflict. The lagoon's open access property regime was repealed when it became a 'no-go zone', where any movement was controlled directly by orders of the STF, and indirectly by threats of abduction and harassment from both military groups, the army 
and the LTTE. According to reports of the fishermen, the STF frequently suspected them to be LTTE collaborators, and they therefore had to undergo regular checks, interrogations, and harassment. Up to the signing of the ceasefire in early 2002, the STF had to a large extent retaken control of the eastern shores of the lagoon, including the Mavilangathurai surroundings. During this time, nobody was allowed to fish in the lagoon at night when usually the largest amount of fish could be caught. Fishermen had to obtain permission from the STF each time they intended to go fishing, and sign in and out before and after departure. Their canoes were kept in a landing site near the army camp, and during times of overt warfare the fishermen could not go fishing at all. The previous institutional setup was replaced by one where the main actors were armed forces of the two parties. The majority of families in Mavilangathurai had to flee the village and take refuge with relatives outside the highly contested areas along the front line. During their absence, which lasted from several months up to two years, many of their houses got ransacked and demolished.

If we examine the development of social and political capital during this time, the accounts of the fishermen point at a complete disruption of social networks in the village (mostly due to temporary migration - people left their homes when violence escalated), also with regard to taking cooperative action on matters of resource use. With the cessation of government support for the FCS and the increasing sway of the two militant parties, the fishermen's professional social capital was diminished in its utility. While local social networks of the fishermen continued to exist outside the FCS, social capital was to a large extent dissociated from political capital. Political capital, on the other hand, was no longer vested in connections to the Sri Lankan government. The previously relatively influential government institutions had virtually disappeared from the village scene. In the case of Mavilangathurai, the institutional space of neither the FCS nor any other village-based institution was filled by an alternative authority during the times of violent conflict of the 1990s. Under these conditions of institutional breakdown, an alternative form of political capital, now understood as linkages either to the LTTE or to the STF, became a powerful and overriding means of obtaining access to the lagoon. If the STF trusted an individual not to be part of the LTTE, he would have easier access to the lagoon and hence be able to derive profit from it through fishing. Often, verifiable contacts to STF soldiers also helped individual fishermen in emergency situations, e.g. when they got imprisoned by the STF on the suspicion of LTTE collaboration. At night, however, the lagoon still was an area that was largely controlled by the LTTE, and fishermen were also abducted and penalised for collaborating with the STF if they lacked the appropriate political capital. 
This illustrates the fishermen's difficult position in the vexed political geographies of war: Due to their dependency on the resources of the strategically important and therefore highly contested lagoon, they found themselves trapped between the power struggles of the two major opponents. Several deaths in crossfire were reported from Mavilangathurai, as well as from several other fishing villages along the lagoon. Political capital, therefore, became a highly ambivalent resource, which could yield profit if it was used very cautiously and appropriately, depending on the ever-changing local and regional political setup of the conflict. As many fishermen had lost their assets (houses, fishing gear) and had thus become economically vulnerable, they often did have no choice other than taking the risk and try to come to terms with the complex political setup by building up political capital with both parties. Their position, however, had to remain ambiguous.

In 2002, when the cease fire agreement (Memorandum of Understanding, MoU) was signed between the Sri Lankan government and the LTTE, violent fighting came to a halt, and both military parties were granted freedom of movement within the areas controlled by the other, provided they were unarmed (MoU, cited in Uyangoda and Perera 2003). The lagoon and its resources were once again opened up for fishing, transport and other civil uses. In the Mavilangathurai area, the LTTE gradually intensified its influence in all social and political domains, thereby increasingly blurring the boundaries between 'cleared' and 'uncleared' areas. Two years after the MoU, the village and its surroundings could be called a 'grey', i.e. contested, border area, where the distinction between cleared and uncleared areas was not clear-cut (Goodhand and Hume 2000: 393). In these areas ipso jure the government is in full control. De facto, however, the LTTE has taken on a considerable proportion of village-level administration by largely non-formalised influence. Former government organizations are only slowly re-established, due to a lack of qualified staff and chronic underfunding of the lower administrational levels. In Mavilangathurai, none of the government-initiated organizations such as the FCS have resumed their work. While the FCS officially still exists, no action has so far been taken to revive it, neither from the fishermen nor from the fisheries department ${ }^{5}$. This also implies that government regulations cannot be implemented because of the lack of enforcement capacities. The institutional breakdown provides a broad space for the LTTE to exercise and increase its rule of power.

After the ceasefire was implemented, the value and expedience of social and political capital once again changed dramatically. In our case, two years after the signing of the MoU,

\footnotetext{
${ }^{5}$ The descriptions of this paragraph are based on data collected in February 2004.
} 
the fishermen's social capital had still not been re-institutionalised in an officially accredited and mutually supported society due to a lack of external assistance (from the government) and an apparent lack of social cohesion in the community. Not surprisingly, informal social networks have deteriorated considerably within the village over the past decade of war. While most families seem to entertain amicable relationships with their neighbours, a majority reported a lack of unity and frequent quarrels in the village. Also, ethnic and religious segregation in the area is extremely high, particularly with regard to the Tamil and the Muslim population. To a lesser extent, Hindu Tamil and Christian Tamil families have also been spatially separated. Economic linkages beyond village boundaries hardly exist. The regained freedom of movement is inhibited by profound individual and communal fears. Social capital, anyhow diminished, is to a great extent contained within ethnic or religious boundaries and within ethnically isolated communities. In Mavilangathurai, most people do not entertain any social contact with the directly neighbouring Muslim village, and only few have social ties with the Christian village. This indicates that social relations become much more refined to the inner kinship bounds and more exclusive towards other ethnic and social groups.

The manifest spatial and social segregation - understood as a lack of social capital - has far-ranging effects on the local political geography, particularly with regard to resource access and use. Among the lagoon fishermen, an increasing issue of dispute is the use of unsustainable fishing methods that have begun to threaten the lagoon ecosystem ${ }^{6}$. Since paddy farming continued to be difficult after the MoU (due to continuing security risks, disputed land claims and the lack of financial capital), the fishing sector rapidly accrued to a major small-scale, household-based livelihood opportunity in Batticaloa district. For many families, fishing suddenly provided new economic opportunities as a major fallback option for those who had lost their assets or the access to it during the war (paddy farmers, cattle herders). By 2004, serious signs of environmental damage were observed by the lagoon fishermen. According to them, overfishing along with other negative developments such as increasing pollution through re-established businesses (in particular slaughterhouses and rice mills), increasing paddy cultivation and ongoing effluents from the municipal sewerage systems, have led to a rapid deterioration of the lagoon ecosystem. A high prevalence of fish diseases and a decline in species variety were observed by fishermen in various villages along the lagoon. Effective fish catches have been declining.

\footnotetext{
${ }^{6}$ In Mavilangathurai, for example, the use of fishing nets with illegally small mesh sizes has been an issue of social conflict.
} 
In the case of Batticaloa lagoon, the responsible government agencies have so far failed to address the newly arising ecological problems, as they are trapped in the political convolution of the ongoing conflict-turned-peace process. District-level government officials generally have a difficult time balancing the requirements of their ministries, while keeping a good working relationship with the parastatal organizations of the LTTE. Besides, most government field offices in the northeast are chronically understaffed due to the harsh working conditions and the limited recruitment of Tamil staff. The Batticaloa office of the Ministry of Fisheries and Ocean Resources, for example, does not have the capacity nor the funds to control access to the lagoon and keep track of the developments of the local fisheries sector. Therefore, while the fishermen have to a great extent regained their customary entitlements to the commons, they experience a partial entitlement failure. Access entitlements are no longer regulated, neither by the rule of law nor by the access restrictions that were enforced by the military actors. Deteriorated and community-bound social capital cannot make up for the institutional failure (e.g. by forming alliances), and environmental degradation and increasing contests over the lagoon resources are mutually reinforcing triggers for social conflict at the intra- and, potentially, at the inter-community level.

There is a threat that resource conflicts may be fought out not only between new and customary users, but also along ethnic or religious lines. Here, the notion of political capital once again comes into play. In Mavilangathurai, fishermen increasingly turn to the LTTE to address the problem of illegal fishing methods in the lagoon. The LTTE, however does not represent the entire population of the area (e.g. Muslims, see below), nor does it have the executive power to tackle the problem on a regional level, with regard to the entire lagoon, not to mention ecosystem factors outside the lagoon vicinity, e.g. the river catchments in the hinterland. It therefore has no other choice than to sanction illicit actions by rigid measures on a case-to-case basis in the communities loyal to them. Political capital employed with regard to LTTE officials can thus be a crucial asset in order to impose sanctions on other perpetrators, or to escape penalties. As a consequence, the already spatially segregated societies or fractions thereof keep on polarising along lines of ethnicity and religious affiliation. Particularly the Muslim community lacks the necessary political linkages to the LTTE, as it does not feel represented and catered for by the organisation. Violent incidents between Muslim and Tamil political groups are frequently observed in Batticaloa district. Increasingly, the Christian population, too, is undergoing a process of active and passive political profiling. Within this process, the renegotiation of entitlements has become a crucial 
though increasingly difficult task towards positive and sustainable conflict transformation in Batticaloa district.

\section{Conclusion: The social dynamics of entitlements and resource access in times of war and conflict transition}

Violent political conflict and civil wars are arenas of dramatic institutional change within brief periods of time, leaving behind often very fragile systems of rules and governance. A better understanding of how the political geographies of war alter institutions is, as we have set out at the beginning of the paper, essential if one wants to 'get the institutions right' in post-war reconstruction processes. Since common-pool and open access resources are significant sources of rural livelihoods, they have often become part of the political economy of war. The two case studies from Sri Lanka's northeast have illustrated how the distribution of social and political capital assets and the field in which these can be brought into effect, have become fragile, ethnicised and exclusive rather than inclusive. In effect, social and political networks often mirror the broader struggle of the civil war.

The first case on the Allai Extension Scheme underlines how farmers use their relative bargaining power that is largely derived from political capital, i.e. their alliances with combatants, to derive benefit streams from resources that are not legally theirs. In effect, this also leads to a refinement of social relations towards the 'ethnic self', excluding the 'ethnic other'. Two aspects play a role: on the one hand, farmers benefit from this seizure of resources at the expense of the 'ethnic other', on the other hand, the grievances propagated in and deepened through warfare, provide an ideological and moral justification for such behaviour. The logic of this ethnicisation - strengthening political capital assets along ethnic lines - seriously undermines peace building activities and the restoration of 'neutral' governance structures to regulate access to essential livelihood resources.

As the second case study has illustrated, the transition of the conflict from a state of warfare to a state of ceasefire has led to altered common property regimes among the users of Batticaloa lagoon. While basic access to the resource has been re-established for traditional fishermen, new resource users have increased the ecological pressure on the lagoon ecosystem, leading to negative social and environmental outcomes. In terms of environmental repercussions of the transition process, increased pollution, increased numbers of fishermen and the use of unsustainable fishing methods jeopardize the sustainability of the entire 
ecosystem. Since the society at large - including the fishing communities along the lagoon has become spatially segregated and in the same time ethnically polarised, the potential for local-level conflicts is high. At the current highly volatile state of the peace process, the issue of environmental entitlements cannot be addressed adequately by the responsible institutions, as they are trapped in the convolutions of the conflict. Already, issues of local resource use show a tendency towards politicisation within the broader institutional setup of the conflict.

Horizontal intra-group linkages (based on social capital) and dissociation from the "ethnic other' can lead to internally strengthened, but highly segregated ethnic or religious communities that may be prone to political instrumentalisation from radical groups within the community and to victimisation from external communities' powerholders. Vertical political contacts and alliances (political capital) to a large extent determine a group's ability to instrumentalise ethnicity or religious affiliation. In both cases, where access rights have been altered as an effect of the political dynamics of the conflict, and where actors voluntarily and proactively change entitlement schemes by polarisation and ethnicisation, the observed dynamic is directly linked to the particular political condition of warfare and the subsequent processes of social and political transition. The institutional failure is used to satisfy a group's own interests by redistributing resource entitlements in a blurred legal framework. As in the case of the Allai irrigation scheme, these unruly social practices can fill the institutional gap and transform the political geographies of war at the local level. Certain groups may profit from the ethnicisation of resource entitlements, while others are left with an entitlement failure and, in the realm of political cleavages find it difficult to make claims to their entitlements.

Indeed, this re-arrangement of social and political capital can have serious repercussions on the peace building process. In Sri Lanka, this is signified in the fact that since the signing of the ceasefire agreement, ethnic tension and even violence has increased significantly on the community level between Tamils and Muslims in both research areas, which has its roots largely due to the perceptions of either side that the other would have gained an unjustified political advantage over access to resources. Competition over resource access easily becomes framed in terms of life and death, the ethnic self and the ethnic other. It is therefore not only the national level where the Sri Lankan government needs to negotiate an agreement with the LTTE. Also, the smaller struggles on the local and regional level need to be resolved within an institutional frame which is acceptable for all local stakeholders, and this most likely will be a challenging task, as the case studies have shown. The Sri Lanka experience 
underlines how crucial it is to study the commons at war as part of a broader process towards peaceful and sustainable development. 


\section{References}

Alston, L.J., Libecap G. D. and Mueller, B. (1999): Titles, Conflict, and Land Use. The Development of Property Rights and Land Reform on the Brazilian Amazon Frontier. Ann Arbor: The University of Michigan Press.

Baechler, G. et al. (1996): Kriegsursache Umweltzerstörung [Environmental Degradation as a Cause of War]. Three Volumes. Zurich: Rüegger.

Balasundarampillai, P. (2002): Trincomalee: Geopolitics, Ethnic Dimension and Development Potential. Thirunelvely: Sociological Society, University of Jaffna.

Baumann, P. (2000): 'Sustainable Livelihoods and Political Capital: Arguments and Evidence from Decentralisation and Natural Resource Management in India', ODI Working Paper 136. London: Overseas Development Institute (ODI).

Bourdieu, P. (1985): Sozialer Raum und ,Klassen’: Leçon sur la Leçon. Frankfurt: Suhrkamp.

Bourdieu, P. (1992): 'Ökonomisches Kapital - Kulturelles Kapital - Soziales Kapital'. In: Die verborgenen Mechanismen der Macht - Schriften zu Politik und Kultur 1. Hamburg: VSA Verlag.

Bourdieu, P. (1993): Sociology in Question. London: Sage Publications.

Bourdieu, P. (2000): Propos sur le champ politique. Lyon: Presses Universitaires de Lyon.

Bush, K. D. and Opp, R. J. (1999): 'Peace and Conflict Impact Assessment'. In: Buckles (ed.): Cultivating Peace: Conflict and Collaboration in Natural Resource Management. Ottawa: International Development Research Centre. 185-202.

Collier, P. and Hoeffler, A. (2002): 'Greed and Grievance in Civil War', Working Paper Series 2002-01. Oxford: Center for the Study of African Economies, Oxford University.

De Soysa, I. (2002): 'Paradise Is a Bazaar? Greed, Creed and Governance in Civil War, 198999', Journal of Peace Research 39 (4), 395-416.

Democratic Socialist Republic of Sri Lanka (DSRoSL) (2001): Administration Report, Department of Fisheries and Aquatic Resources. Colombo: Ministry of Fisheries and Ocean Resources.

Elwert, G. (1997): 'Gewaltmärkte. Beobachtungen zur Zweckrationalität der Gewalt', in T. von Trotha (ed.): Soziologie der Gewalt, 86-101. Opladen: Westdeutscher Verlag.

Goodhand, J. and Hulme, D. (1999): 'From Wars to Complex Political Emergencies: Understanding Conflict and Peace-building in the New World Disorder', Third World Quarterly 20 (1), 13-26. 
Gore, C. (1993): 'Entitlement Relations and Unruly Social Practices: A Comment on the Work of Amarthya Sen', Journal of Development Studies 29 (3), 429-460.

Hauge, W. and Ellingsen, T. (1998): 'Beyond Environmental Security: Causal Pathways to Conflict', Journal of Peace Research 35 (3), 299-317.

Hennayake, S.K. (1985): Geographical Perspectives on Ethnicity in Sri Lanka. Unpublished M.A. Thesis. Department of Geography, University of Peradeniya.

Homer-Dixon, T.F. (1999): Environment, Scarcity and Violence. Princeton: Princeton University Press.

Keen, D. (1997): 'A Rational Kind of Madness', Oxford Development Studies 25 (1), 67-75.

Keen, D. (1998): 'The Economic Functions of Violence in Civil Wars'. Adelphi Paper 320. London: International Institute of Strategic Studies with Oxford: Oxford University Press.

Korf, B. (2003a): 'Control over Land: Competing Claims and Fuzzy Property Rights in the Northeast of Sri Lanka', Roadmap Discussion Paper. Colombo: Berghof-Foundation for Conflict Studies.

Korf, B. (2003b): 'Geographien der Gewalt: Handlungsorientierte geographische Bürgerkriegsforschung in politisch-ökonomischer Perspektive', Geographische Zeitschrift 91, 1, 24-39.

Korf, B. (2004): 'War, Livelihoods, and Vulnerability in Sri Lanka', Development and Change 35 (2), 277-297.

Leach, M., Mearns, R. and Scoones, I. (1999): 'Environmental Entitlements: Dynamics and Institutions in Community-based Natural Resource Management', World Development 27 (2), 225-247.

Manogaran, C. (1987): Ethnic Conflicts and Reconciliation in Sri Lanka. Honolulu: University of Hawaii.

Mearns, R. (1995): 'Institutions and natural resource management: Access to and control over woodfuel in East Africa', in T. Binns (ed.): People and Environment in Africa. Chichester: John Wiley and Sons. 103-114.

Peiris, G.H. (1991): 'An Appraisal of the Concept of a Traditional Homeland in Sri Lanka', Ethnic Studies Report 9 (1), 13-39

Peiris, G.H. (1994): 'Irrigation, Land Distribution and Ethnic Conflict in Sri Lanka: An Evaluation of Criticism, with Special Reference to the Mahaveli Programme', Ethnic Studies Report 12 (1), 43-88.

Portes, A. (1998): 'Social Capital: Its Origins and Applications in Modern Sociology'. In: Annual Review of Sociology 24: 1-24. 
Ribot, J.C. and Peluso, N.L. (2003): 'A Theory of Access'. In: Rural Sociology 68 (2), 153181.

Sen, A.K. (1981): Poverty and Famines. An Essay on Entitlements and Deprivation. Oxford: Clarendan.

Suliman, M. (1999): 'The Nuba Mountains of Sudan: Resource access, violent conflict, and identity'. In: Buckles (ed.): Cultivating Peace: Conflict and Collaboration in Natural Resource Management. Ottawa: International Development Research Centre. 205-220.

Tambiah, S. (1986): Sri Lanka: Ethnic Fratricide and the Dismantling of Democracy. Chicago: Chicago University Press.

Thangarajah, Y. (2003): 'Ethnicization of the Devolution Debate and the Militarization of Civil Society in North-Eastern Sri Lanka', in Mayer, M.; D. Rajasingam-Senanayake and Y. Thangarajah (eds.): Building Local Capacities for Peace: Rethinking Conflict and Development in Sri Lanka, 15-36. Delhi: Macmillan.

Unruh, J.D. (1998): 'Land Tenure and Identity Change in Post-war Mozambique', GeoJournal 46, 89-99.

Unruh, J.D. (2001): 'Postwar Land Dispute Resolution: Land Tenure and the Peace Process in Mozambique', International Journal on World Peace 18 (3), 3-29.

Uphoff, N. (1996): Learning from Gal Oya: Possibilities for Participatory Development and Post-Newtonian Social Science. London: IT Publications.

Uyangoda, J. and Perera, M. (eds.) (2003): Sri Lanka's Peace Process 2002: Critical perspectives. Colombo: Social Scientists Association. 